\title{
切干大根製造工程における青首大根とアザキ大根の
} 遊離アミノ酸組成の比較

水野時子* ・佐々木弘子**

(*郡山女子大学短期大学部, **聖徳大学)

(平成27年6月12日受付，平成27年10月28日受理)

\section{Comparison of the free amino acid composition of the Aokubi daikon and Azaki daikon in the dried shredded daikon manufacturing process}

\author{
Tokiko Mizuno *, Hiroko Sasaki ** \\ *Koriyama Women's College, 3-25-2, Kaisei, Koriyama-shi, Fukushima, 963-8503 \\ ** Seitoku University, 550, Iwase, Matsudo-shi, Chiba, 271-8555 \\ * =963-8503 福島県郡山市開成 3-25-2 \\ ***271-8555 千葉県松戸市岩瀬550
}

\begin{abstract}
The purpose of this research study is to examine the functionality of dried shredded Azaki daikon. To achieve this, we compared the free amino acid content of the boiled, raw-dried and boiled-dried forms between the Aokubi daikon and Azaki daikon.

The boiling procedure decreased the glutamine, $\gamma$-aminobutyric acid and proline in both the Aokubi daikon and Azaki daikon; decreases in the $\gamma$-aminobutyric acid were especially notable. When comparing the raw-dried daikon to the boiled daikon, the total free amino acids of glutamine, $\gamma$-aminobutyric acid and proline, the levels in the boiled daikon were lower in both the Aokubi dried shredded daikon and the Azaki dried shredded daikon. The glutamine, $\gamma$-aminobutyric acid, arginine and glutamic acid contents were higher in the dried shredded Azaki daikon, and arginine content, in particular, was significantly higher.

Our results indicated that the dried shredded daikon showed changes in glutamine, $\gamma$-aminobutyric acid, proline, and glutamic acid contents when processed by boiling. In addition, the dried shredded daikon using Azaki daikon, one of the traditional vegetables in the Aizu region, has a higher amount of amino acids, and is more responsible for its taste than the Aokubi daikon, and is anticipated to have amino acidrelated functional effects.
\end{abstract}

\section{1. 緒言}

わが国を代表する伝統的乾燥野菜の 1 つに切干大根が ある。切干大根の加工形態は地域によりさまざまである が，生の大根を裁断し乾燥させた生干しは，天日乾燥す ることで甘味が増し特有の風味が加わることが知られて いる。一方, 乾燥前に熱処理（蒸し処理）を施してから 乾燥させた切干大根は, 加熱による酵素の失活により褐 変を防止することや糖の流出で甘味が淡いことが報告さ
れている1)。また, 乾燥加工した大根はミネラル, 特に カルシウム, マグネシウム, 鉄の有効な摂取方法である ことが報告されている ${ }^{2)}$ 。

福島県会津地方の伝統野菜の一つにアザキ大根がある。 アザキ大根の名前の由来は，食用の大根に似ているが， 硬く, 辛みが強く, 人を“欺く”という意味から名付け られたといわれている。地元では辛さの特徴を生かして 「高遠そば」の薬味に用いられてはいるが, 消費量は少 ない。筆者らは先に ${ }^{3)}$, アザキ大根は青首大根や赤筋大 
(mg/100 g dry matter basis)

\begin{tabular}{|c|c|c|c|c|c|c|c|c|}
\hline & \multicolumn{4}{|c|}{ 青首大根 } & \multicolumn{4}{|c|}{ アザキ大根 } \\
\hline & 生大根 & 茹で大根 & 生干し大根 & $\begin{array}{c}\text { 茹で干し } \\
\text { 大根 }\end{array}$ & 生大根 & 茹で大根 & 生干し大根 & $\begin{array}{c}\text { 茹で干し } \\
\text { 大根 }\end{array}$ \\
\hline Aspartic acid (Asp) & 241.6 & 178.8 & 88.0 & 175.6 & 337.5 & 272.0 & 213. 2 & 266.1 \\
\hline Threonine (Thr) & 74.1 & 52.9 & 60.0 & 50.0 & 220.2 & 146.0 & 199.5 & 152.2 \\
\hline Serine (Ser) & 88.3 & 64.9 & 77.6 & 61.4 & 224.1 & 166.5 & 196.0 & 140.7 \\
\hline Glutamic acid (Glu) & 248.1 & 296.8 & 209.2 & 318.5 & 440.7 & 681.5 & 390.3 & 608.2 \\
\hline Proline (Pro) & 157.5 & 50.8 & 402.8 & 87.1 & 46.4 & 39.2 & 230.0 & 34.8 \\
\hline Glycine (Gly) & 25.7 & 17. 9 & 26.4 & 12.9 & 27. 1 & 13.5 & 20.9 & 12.5 \\
\hline Alanine (Ala) & 80.2 & 55.0 & 186.1 & 44. 4 & 198. 1 & 152.4 & 155.9 & 103. 2 \\
\hline Valine (Val) & 149.3 & 100.6 & 121.5 & 94.5 & 267.8 & 202.2 & 241.7 & 186.5 \\
\hline Methionine (Met) & 6.3 & 4. 2 & 7.0 & 0.9 & 3.6 & 2.6 & 4.2 & 2.6 \\
\hline Isoleucine (Ile) & 102.3 & 67.9 & 79.1 & 64.3 & 146.4 & 129.1 & 142.0 & 117.2 \\
\hline Leucine (Leu) & 14.6 & 9.3 & 6.8 & 10.9 & 63.6 & 49.6 & 44.3 & 47.5 \\
\hline Tyrosine (Tyr) & 10.8 & 8. 0 & 4.1 & 7.5 & 43.8 & 36.8 & 34.5 & 40.0 \\
\hline Phenylalanine (Phe) & 62.5 & 32.5 & 17.5 & 31.7 & 34.1 & 30.2 & 21.7 & 31.9 \\
\hline Lysine (Lys) & 20.5 & 17.1 & 5.0 & 12.4 & 72.0 & 73.2 & 49.9 & 61.6 \\
\hline Histidine (His) & 33.4 & 25.4 & 22.9 & 15.7 & 86.8 & 81.5 & 84.8 & 67.3 \\
\hline Arginine (Arg) & 62.3 & 111.4 & 33.9 & 63.8 & 952.2 & $1,010.7$ & 827.3 & 672.5 \\
\hline Phosphoserine (P-Ser) & 79.8 & 116.4 & 37.7 & 116.4 & 45.5 & 119.9 & 53.8 & 159. 7 \\
\hline Asparagine (Asn) & 49.6 & 36.9 & 43.6 & 32.3 & 114.1 & 94.7 & 111.5 & 80.6 \\
\hline Glutamine (Gln) & 632.9 & 431.2 & 448.9 & 344.9 & 966.0 & 686.9 & 756.5 & 396.4 \\
\hline$\gamma$-Amino butyric acid (GABA) & 206.4 & 28.8 & 112.9 & 33. 1 & 424.3 & 69.5 & 302.8 & 68.2 \\
\hline 総 量 & $2,346.2$ & $1,706.8$ & $1,991.0$ & $1,578.3$ & $4,714.3$ & $4,058.0$ & $4,080.8$ & $3,249.7$ \\
\hline
\end{tabular}

各 2 点分析し平均值として示した。

根に比べて水分が少なく，タンパク質，脂質，カリウム， 鉄，亜鉛などの栄養成分含量が高いこと，また遊離アミ ノ酸総量も高く, 特にグルタミン $(\mathrm{Gln}), \quad \gamma$ ーアミノ酪 酸（GABA），アルギニン（Arg）を特異的に高含有して いることを報告した。Gln, GABA, Argは，生体内に おいて特有の機能性を有することが明らかとなってい

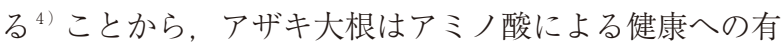
用性が期待できる食材であると考える。アザキ大根を薬 味として食するだけでなく，切干大根に用いることで契 食量の増大につながり, さらにミネラルの有効な摂取 ${ }^{2)}$ に加えてアミノ酸による機能性も期待できることから, アザキ大根の消費拡大にもつながると考える。そこで， アザキ大根を用いた切干大根の機能性を検討することを 目的に，アザキ大根の切干大根製造工程における遊離ア ミノ酸組成を青首大根と比較し検討した。

\section{2. 実験方法}

\section{（1）実験試料および調整方法}

実験には，郡山市内のスーパーで購入した生鮮青首大 根と会津金山町の生産農家より入手した生鮮アザキ大根 を用いた。それぞれの大根は，皮付きのまま大根全体を 幅約 $2 \mathrm{~mm}$ の千切りにし，部位が偏らないようよく混合 して用いた。千切りにした生の大根を「生大根」とし,「生 大根」を水道水の熱湯に入れ 2 分間茹でてザルで湯切り
した「茹で大根」,「生大根」「茹で大根」をそれぞれザ ルに広げガラス越しの室内で 3 日間自然乾燥した「生干 し大根」,「茹で干し大根」を作り, アミノ酸分析に供し た。

\section{（2）実験方法}

水分は $105^{\circ} \mathrm{C}$ 常圧加熱乾燥法 ${ }^{5)}$ により分析した。遊離 アミノ酸の抽出は，試料に $75 \%$ エチルアルコール溶液を 加え, $80^{\circ} \mathrm{C}$ で30分間還流抽出（3 回繰り返し抽出）を行 い, 抽出液をエバポレーターを用い減圧下で乾固し,

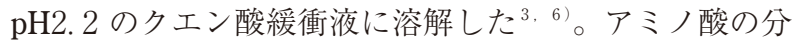
析は，得られた溶液を $0.20 \mu \mathrm{m}$ のフィルターでろ過し， 日立L-8800型高速アミノ酸自動分析機を用いて, 生体 液分析法により行った。

\section{3. 実験結果および考察}

青首大根とアザキ大根を用いた「生大根」,「茹で大根」, 「生干し大根」,「茹で干し大根」の遊離アミノ酸組成を 乾物換算 $100 \mathrm{~g}$ 当たりで表 1 に示した。

\section{（1） 前報資料の追試 ${ }^{3}$}

生アザキ大根（「生大根」）の遊離アミノ酸総量は, $4,714.3 \mathrm{mg}$ で青首大根（「生大根」）の2, 346.2 mg より も高值であった。主要なアミノ酸は, 生青首大根（「生 
青首大根

口酸味系・旨味系 口苦味系 口甘味系

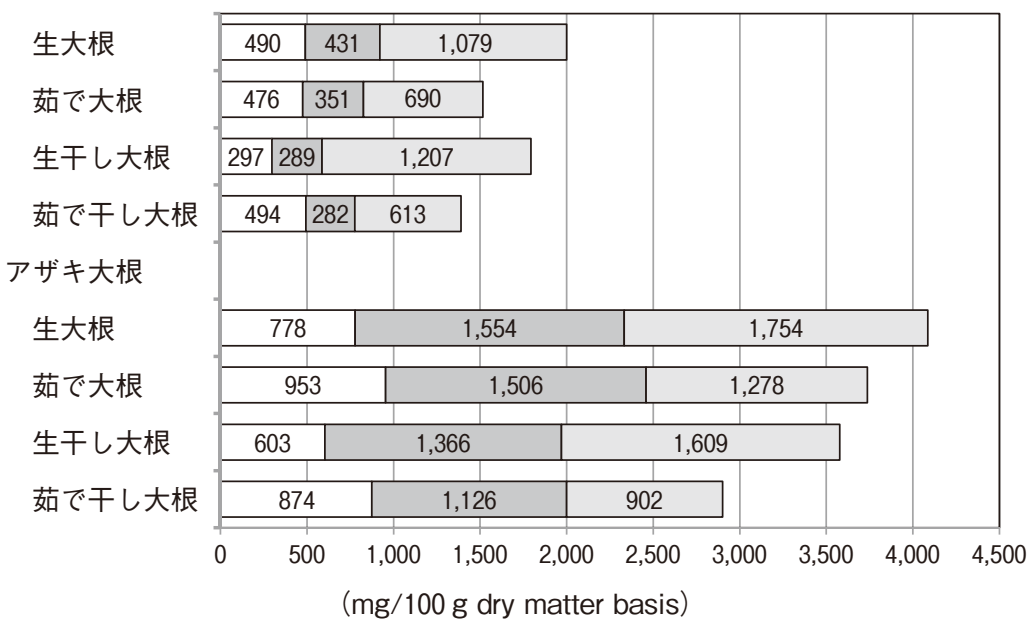

図 1 切干大根製造工程における呈味性アミノ酸含量の変動

酸味系・旨味系：Asp. Glu苦味系 : Phe, His, Arg, Ile, Val, Leu, Met

甘味系 : Gly, Ala, Thr, Ser, Pro, Lys, Gln

大根」), 生アザキ大根 (「生大根」) とも Gln, グルタミ ン酸 (Glu)，アスパラギン酸 (Asp)， GABA で，さら にアザキ大根は Arg であった。それら 5 つのアミノ酸 (Gln, Glu, Asp, GABA, Arg) のそれぞれの含量は, 生青首大根に比べて生アザキ大根が高值であった。特に $\operatorname{Arg}$ は生青首大根 $62.3 \mathrm{mg}$ に対して生アザキ大根 $952.2 \mathrm{mg}$ で，それぞれの生大根の遊離アミノ酸総量に 占める割合は青首大根 $2.7 \%$, アザキ大根 $20.2 \%$ であった。 アザキ大根は，先の報告 ${ }^{3)}$ と同様に青首大根に比べて遊 離アミノ酸総量が高く, 特に Arg 含量は10倍以上, 口 イシンおよびチロシンが 5 倍程度の高值であった。

\section{（2）茹で処理による大根中の遊離アミノ酸の変動}

生大根に茹で処理を行うことにより青首大根，アザキ 大根とも遊離アミノ酸総量, GABA, プロリン (Pro), Gln が減少し，特に青首大根，アザキ大根とも GABAの 減少が著しかった。Gluは Gln, GABA, Pro と異なり 増加し，青首大根では約1.2倍，アザキ大根では約1.5倍 の高值であった。大根の茹で操作による Gln, GABA, Pro 含量の減少は, 茹で溶液中に溶出したものと示唆さ れた。

\section{（3）乾燥処理による大根中の遊離アミノ酸の変動}

生大根に乾燥処理（干し操作）を行うことにより青首 大根，アザキ大根とも遊離アミノ酸総量，Glu，Asp が 減少し, 乾燥による代謝にかかわって消費されたものと 思われた。一方, Pro は増加した。Proの増加は青首大 根2.6倍，アザキ大根5. 0倍の高值であった。これら生大 根を乾燥した際の Glu, Asp, Pro の変動は，久松ら ${ }^{7)}$ の報告と同様であった。茹で大根では乾燥処理を行うこ とにより，Arg, Gln が減少した。

多くの植物は環境ストレスを受けると細胞内にPro を 蓄積することが報告されている ${ }^{8)}$ 。本研究では，生大根
に乾燥処理（干し操作）を行うことで水ストレスとなり Proが蓄積したと推測された。Pro 含量は青首大根およ びアザキ大根とも茹で大根と茹で干し大根の比較では差 は小さいことから，生干し大根でのProの蓄積は，スト レスに伴うPro を生合成する酵素活性，Pro 生合成にか かわる遺伝子鍵酵素発現が関与していると考えられる。 Pro は活性酸素の除去など9)の役割を果たしていること が報告されている。また，水ストレス下の植物細胞は Pro 濃度の増大と共に Asp, Glu 濃度が減少することが 報告 ${ }^{7)}$ されている。これは細胞の代謝系が Pro の生合成 にシフトした結果，その材料およびエネルギーの供給等 のため，遊離の Asp，Glu が消費したものと考えられた。

\section{（4）茹で干し大根の遊離アミノ酸の変動}

生干し大根に対して茹で干し大根は，青首大根，アザ キ大根とも遊離アミノ酸総量, Gln, GABA, Pro が低 值で，Glu は高值であった。生大根に茹で操作を行うこ とにより変動したアミノ酸の変動と同様であったことか ら, 切干大根のアミノ酸組成は乾燥前に行う茹で操作の 影響が大きいことが示された。

\section{（５）切干アザキ大根の機能性}

近年, 個々のアミノ酸の生理作用が明らかとなり, Gln は腸管のエネルギー供給・修復作用等, GABA は血 圧上昇抑制作用等, $\operatorname{Arg}$ は成長ホルモン分泌促進作用等 が報告 ${ }^{4)}$ され, Arg は Gln とともに免疫機能低下抑制作 用から免疫強化経腸栄養剂の特殊成分としても用いられ ている ${ }^{10)}$ 。青首大根を用いた切干大根に比べてアザキ大 根を用いた切干大根は, 生干し大根, 茹で干し大根とも Gln, GABA，Arg 含量は高值で, 生干し大根では Gln 1. 7倍, GABA 2.7倍, $\operatorname{Arg} 24.4$ 倍, 茹で干しは Gln 1. 1倍, GABA 2.1倍, Arg 10.5倍であった。特に Arg は, 生干 し大根，茹で干し大根とも含量が高いことから，薬味程 
度に使われるアザキ大根を用いた食べやすい切干大根の 量的摂取が可能であることにより $\operatorname{Arg}$ の生理機能が期 待できる。また GABA 摂取は血圧上昇抑制作用により 軽度高血圧者に対して 1 日 $20 \mathrm{mg}$ の摂取が妥当であろう との報告 ${ }^{11)}$ がある。アザキ大根を用いた生干し大根を製 品として7. $5 \mathrm{~g}$ 摂取することで $\mathrm{GABA} 20 \mathrm{mg}$ の摂取が可 能であり, GABAの機能性が期待できる。しかし, GABA は水溶性であることから調理上の工夫が必要であ る。

\section{（6）切干大根製造工程による呈味性アミノ酸の変動}

切干大根製造工程による呈味性アミノ酸の変動を図 1 に示した。

生アザキ大根（「生大根」）は, 生青首大根 (「生大根」) に比べて酸味・旨味系アミノ酸, 苦味系アミノ酸, 甘味 系アミノ酸とも高值であった。特に Arg 含量の違いに より苦味系アミノ酸含量に顕著な違いがみられた。生大 根に茹で操作を行うことで青首大根，アザキ大根とも，

Gln 含量の減少により甘味系アミノ酸含量が低下した。

乾燥後も乾燥前の茹で操作の有無により甘味系アミノ 酸含量に違いがみられ，青首大根，アザキ大根とも茹で 干し大根は生干し大根に比べて甘味系アミノ酸が著しく 低值であった。茹で干し大根は生干し大根に比べて持丸 ら ${ }^{1)}$ の報告による糖の流出だけでなく，アミノ酸の観点 からも甘味が淡いことが認められた。また，アザキ大根 を用いた切干大根は青首大根を用いた切干大根に比べて, 生干し, 茹で干しともそれぞれの呈味性アミノ酸含量が 高いことから，アミノ酸の観点から呈味性が強かったこ

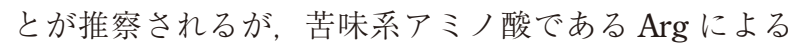
苦味が呈された。しかし，Argの苦味抑制成分について の報告 ${ }^{12)}$ もあることから，健康に関する機能性食材とし て期待される。

\section{4. 要 約}

アザキ大根を用いた切干大根の機能性を検討すること を目的に，アザキ大根の切干大根製造工程に打ける遊離 アミノ酸組成を青首大根と比較し検討した。

(1) 大根は茹で操作により, 遊離アミノ酸総量, グル夕 ミン， $\gamma$ ーアミノ酪酸, プロリンが減少し, 特に $\gamma$ ーア ミノ酪酸の減少が著しかった。

(2) 茹で干し大根は生干し大根に比べて, 遊離アミノ酸 総量, グルタミン， $\gamma$-アミノ酪酸, プロリンが低值
であった。

(3) アザキ大根を用いた切干大根は，青首大根を用いた

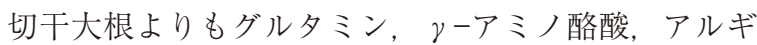
ニンが高值で，加工により減少するが，特にアルギニ ンが顕著に高値であった。また，干すことにより，プ ロリンが顕著に増加した。

これらのことから，切干大根は製造工程としてブラン チング (茹で操作) を行うことにより遊離アミノ酸組成 に違いがみられた。また会津地方の伝統野菜の一つであ るアザキ大根，それを用いた切干大根は青首大根を用い た切干大根よりも，機能性アミノ酸含量が高いことから それらの機能性が期待できるものと思われる。

\section{文献}

1）持丸由香, 冨田圭子, 大谷貴美子, 吉野世美子, 南出隆久： 大根の乾燥, 水戻し過程に扔ける糖とミネラルの変化, 調 理科学, 40, 456-461 (2007)

2 ）中田由香, 冨田圭子, 大谷貴美子, 南出隆久, 吉野世美子： 大根の糖及びミネラルの季節と乾燥操作による変動, 京都 府立大学学術報告「人間環境学・農学」, 57, 7-11（2005）

3）善方美千子, 水野時子, 山田幸二：会津の伝統野菜「ア ザキ大根」の一般成分, 無機質, 遊離アミノ酸, 日本食生 活学会誌, 17, 40-43 (2006)

4）日本必須アミノ酸協会編：たんぱく質・アミノ酸の科学 工業調査会，東京，p.229-234（2007）

5 ) 日本食品科学工学会委員会：新 - 食品分析法, 光琳, 東京, p. 6-9, (1996)

6) 日立ハイテクノロジーズ：(L-8800A 形高速アミノ酸分析 計扮客様用取扱説明書（本体編）2004）

7 ） 久松裕子, 遠藤伸之, 長尾慶子：調理性・嗜好性および 抗酸化性から検討した半乾燥干し野菜の調理条件, 日本家 政学会誌, 64, 137-146（2013）

8 ） L. テイッ, E. ザイガー編, 西谷和彦, 島崎研一郎監訳 : 植物生理学 第 3 版, 培風館, 東京, p.601-634（2004）

9 ) Smirnoff N., Cumbes Q.J.: Hydroxyl radical scavenging activity of compatible solutes, Phytochemistry, 28, 1057-1060 (1989)

10）上野麻也子, 谷崎久之：日本に打ける免疫強化経腸栄養 剂について，栄養学雑誌，64，221-228（2006）

11）土田隆, 益子研土, 山田勝彦, 平塚秀雄, 島田孝男, 板 垣雪絵, 藤沼秀光, 鮫島浩二, 中村寿雄, 長谷川節, 松林 恒夫：血圧が高めの健常者および軽症高血圧に対する $\gamma$-ア ミノ酪酸高含有クロレラの効果, 栄食誌, 56, 97-102 (2003)

12）道川恭子, 鴻巣章二：ホタテガイ合成エキス中のアルギ ニンの苦味抑制成分の同定, 日食科工誌, 42, 982-988 (1995) 